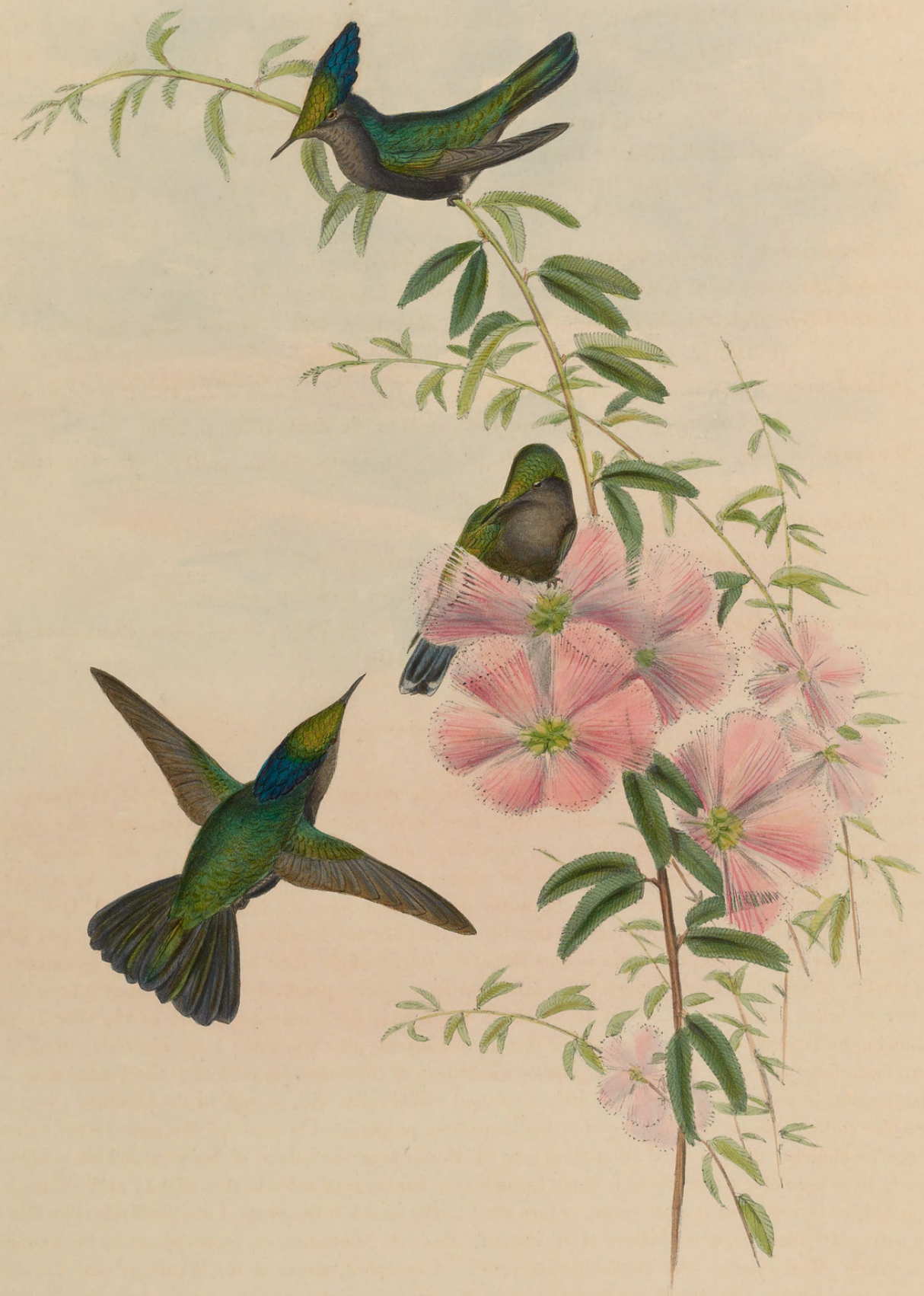




\section{ORTHORHYNCHUS CRISTATUS.}

Blue-Crest.

Trochilus cristatus, Linn. Syst. Nat., tom. i. p. 192.-Ib. Gmel. Edit., tom. i. p. 498.-Lath. Ind. Orn., tom. i. p. 317.-Swains. Birds of Brazil, pl. 21.-Vieill. Ency. Méth. Orn., part 2. p. 565. pl. 131. fig. 3.-Schomb. Hist. of Barbadoes, p. 681.

Mellisuga cristata, Briss. Orn., tom. iii. p. 714. pl. xxxvii. fig. 2.-Id. 8vo, tom. ii. p. 35.-Gray and Mitch. Gen. of Birds, vol. i. p. 113, Mellisuga, sp. 98.

L'Oiseau-mouche huppé, Buff. Hist. Nat. des Ois., tom. vi. p. 22.-Ib. Sonn. Edit., tom. xvii. p. 173.

L'Oiseau-mouche huppé de Cayenne, Buff. Pl. Enl. 227. fig. 1.

Crested Humming-bird, Edw. Nat. Hist. of Birds, vol. i. p. 37. pl. 37.

Crested Green Humming-bird, Lath. Gen. Syn., vol. ii. p. 783.-Shaw, Gen. Zool., vol. viii. p. 352. pl. 44.-Lath. Gen. Hist., vol. iv. p. 339.

Orthorhynchus cristatus, Bonap. Consp. Gen. Av., p. 83, Orthorhynchus, sp. 1.-Reichenb. Aufz. der Colibris, p. 11.-Bonap. Rev. et Mag. de Zool. 1854, p. 256.

Ornismya cristata, Less. Les Troch., p. 20. pl. 4.—Ib. Traité d'Orn., p. 285.--Ib. Ind. Gen. et Syn. des Ois. du Gen. Trochilus, p. xxx.

Trochilus pileatus, Lath. Ind. Orn., vol. i. p. 318. puniceus, Gmel. Edit. Linn. Syst. Nat., tom. i. p. 497.

L'Oiseau-mouche à huppé bleue, Aud. et Vieill. Ois. dor., tom. i. p. 112. pl. 63.

Crested Brown Humming-bird, Lath. Gen. Syn., vol. ii. p. 784.-Shaw, Gen. Zool., vol. viii. p. 354.-Lath. Gen. Hist., vol. iv. p. 340.

IT will have been noticed, while perusing the pages of the present work, that many species of Hummingbirds are confined to very small areas of country, some to the cones of lofty mountains, and some to the craters of extinct volcanos, while others are migratory, and extend their range over vast regions. A similar law appears to govern some at least of the species inhabiting the West Indian Islands : for instance, two species are found in Jamaica, which up to the present time have not been detected in St. Domingo; on the other hand, of the St. Domingo species two at least are not found in Jamaica : and not only does this law appear to prevail on those two islands alone, the largest of the West Indian group, but to extend to the smaller islands also, most of them being inhabited by a species peculiarly its own; hence it becomes a matter of much interest to ascertain to which of the islands the numerous species of the West Indian Humming-birds really belong. I am aware that in making the above remarks I am digressing from the more immediate subject of the present paper-the history of Orthorhynchus cristatus; but I have done so intentionally, in order to point out the utter confusion which exists with regard to the localities given by the older authors, whose errors, I regret to say, have been perpetuated by most of the more recent writers on the Trochilidæ; thus, one and all of them give St. Domingo as the habitat of the present bird, while, so far as I have been able to ascertain, it is not found within hundreds of miles of that island; and, although I am unable to give the extent of its range, or how many of the islands it frequents, I can positively state that it is a native of Barbadoes, and I believe of St. Vincent's also. In Martinique its place appears to be occupied by a nearly allied species-the Orthorhynchus exilis. A complete survey of the Windward and Leeward Islands, furnishing an account of the fauna of each, by some competent person, would, in a scientific point of view, be attended with the most interesting results; and I trust the time is not far distant when such a task will be undertaken and accomplished. Up to the present time, numerous examples of this bird, its nest and eggs, have been sent to Europe, but hitherto not one word has been recorded respecting its 
peculiar actions and habits; an account of which would doubtless prove highly interesting, as they probably differ as much from those of the members of the group as the bird does in its form and colouring.

As is very commonly the case among the Trochilidæ, the sexes present a marked difference in appearance, the beautiful crest which adorns the male being entirely wanting in the opposite sex.

Sir Robert Schomburgk found this bird in Barbadoes, and specimens collected by him are contained in the Collection at the British Museum. As will be seen on reference to his "History of Barbadoes," it is the only Humming-bird observed by him in that island.

The male has the forehead and crown rich golden-green, blending into the rich deep blue of the elongated crest-feathers; sides and back of the head, upper surface of the body, wing-and tail-coverts dark grassgreen ; wings purplish-brown; two centre tail-feathers dark purplish-green, the remainder purplish-black; under surface dull black, with a wash of grey on the throat; bill and feet blackish-brown.

The female has the head, all the upper surface, wing- and tail-coverts bronzy-green; wings purplishbrown; central tail-feathers dark bronzy-green, the remainder purplish-black, the two outer on each side slightly tipped with grey; under surface dark smoky-grey, somewhat lighter on the throat.

The accompanying Plate represents two males and a female, of the size of life. The plant is the Calliandra brevipes. 


\section{$2 \mathrm{BHL}$ Biodiversity Heritage Library}

Gould, John. 1857. "Orthorhynchus cristatus, Blue-Crest. [PI. 205]." A monograph of the Trochilidae, or family of humming-birds 4, https://doi.org/10.5962/p.317014.

View This Item Online: https://www.biodiversitylibrary.org/item/108334

DOI: https://doi.org/10.5962/p.317014

Permalink: https://www.biodiversitylibrary.org/partpdf/317014

\section{Holding Institution}

Smithsonian Libraries

\section{Sponsored by}

Smithsonian Institution Libraries

\section{Copyright \& Reuse}

Copyright Status: NOT_IN_COPYRIGHT

This document was created from content at the Biodiversity Heritage Library, the world's largest open access digital library for biodiversity literature and archives. Visit BHL at https://www.biodiversitylibrary.org. 